\title{
Pemodelan Keruntuhan Bendungan Menggunakan HEC-RAS 2D Studi Kasus Bendungan Gondang, Kabupaten Karanganyar
}

\author{
Kiki Marina Murdiani ${ }^{1 *}$, Sri Sangkawati ${ }^{2)}$, Kresno Wikan Sadono ${ }^{3)}$ \\ 1) Mahasiswa Pascasarjana Prodi Magister Teknik Sipil, Universitas Diponegoro \\ 2) 3) Program Studi Magister Teknik Sipil , Universitas Diponegoro Semarang
}

DOI: https://doi.org/10.21107/rekayasa.v13i2.6872

\section{Modelling Dam Collapse Using 2D HEC-RAS \\ (Case Study of Gondang Dam, Karanganyar Regency)}

\begin{abstract}
The construction of a dam provides benefits to the community around the reservoir, but also saves danger if it experiences dam collapse. One of the requirements that must be met before obtaining an operating permit certificate is the RTD (Emergency Action Plan). The benefit of formulating an emergency action plan is to guide the dam managers and the government who are in the area at risk if an emergency condition occurs at the Dam. This paper covers the area affected in the event of dam failure. Utilization of Software uses HEC-RAS with a Gondang Dam case study located in Karanganyar Regency. The affected locations, according to the results of the analysis are Gempolan Village, Ganten Village, Kwadungan Village, Kutho Village, Kerjo District, Karanganyar Regency, Central Java Province. This Dam has a total reservoir of 9.15 million cubic meters with a dam height of 71 meters. Dam failure modeling with 2D under unsteady flow conditions, simulation of collapse due to middle piping at $+495 \mathrm{~m}$ elevation. The results of the Gondang Dam collapse modeling, which will have the most significant impact if there is middle piping due to PMF flooding with peak discharge Qoutflow $=902.40 \mathrm{~m} 3 / \mathrm{sec}$. The speed of flooding due to the collapse of the Dam that reached the fastest settlement was 24 minutes, namely to the village of Gempolan, which is $0.6 \mathrm{~km}$ from the location of the Dam.
\end{abstract}

Keywords: Gondang Dam, dam break, affected area Karanganyar.

\section{ABSTRAK}

Pembangunan bendungan memberikan manfaat untuk masyarakat sekitar waduk, namun juga menyimpan bahaya jika mengalami keruntuhan bendungan. Salah satu syarat yang harus dipenuhi sebelum mendapatkan sertifikat ijin operasi adalah RTD (Rencana Tindak Darurat). Manfaat dari disusunnya rencana tindak darurat adalah untuk pedoman para pengelola bendungan maupun pemerintah yang berada pada daerah yang terkena resiko apabila terjadi kondisi darurat pada Bendungan. Makalah ini mencakup daerah yang terdampak jika terjadi kegagalan bendungan. Pemanfaatan Software menggunakan HEC-RAS dengan studi kasus Bendungan Gondang yang berlokasi di Kabupaten Karanganyar. Lokasi terdampak menurut hasil analisis adalah Desa Gempolan, Desa Ganten, Desa Kwadungan, Desa Kutho, Kecamatan Kerjo, Kabupaten Karanganyar, Provinsi Jawa Tengah. Bendungan ini mempunyai tampungan total 9,15 juta meter kubik dengan tinggi bendungan 71 meter. Pemodelan keruntuhan bendungan dengan 2D pada kondisi unsteady flow, simulasi keruntuhan akibat piping tengah pada elevasi $+495 \mathrm{~m}$. Hasil pemodelan keruntuhan Bendungan Gondang yang akan menimbulkan dampak paling besar jika terjadi piping tengah akibat banjir PMF dengan puncak debit Qoutflow $=902,40 \mathrm{~m} 3 /$ det. Kecepatan banjir akibat keruntuhan bendungan tercepat yang sampai ke pemukiman adalah 24 menit yaitu sampai di Desa Gempolan yang berjarak 0,6 $\mathrm{km}$ dari lokasi bendungan.

Kata Kunci: Bendungan Gondang, dam break, daerah terdampak Karanganyar.

\section{PENDAHULUAN}

Bendungan Gondang merupakan bendungan multipurpose dengan tampungan total 9,15jt $\mathrm{m}^{3}$. Daerah aliran sungai Bendungan Gondang seluas $20,19 \mathrm{~km}^{2}$ dengan panjang sungai utama $14,33 \mathrm{~km}$. Bendungan selain bermanfaat, terdapat pula potensi bahaya jika terjadi keruntuhan. Oleh karena itu dibutuhkan analisis dan simulasi jika bendungan mengalami kegagalan. Bendungan Gondang merupakan

\section{Article History:}

Received: March, $9^{\text {th }}$ 2020; Accepted: May, $10^{\text {th }} 2020$

REKAYASA ISSN: 2502-5325 has been Accredited by Ristekdikti (Arjuna) Decree: No. 23/E/KPT/2019 August $8^{\text {th }}$, 2019 effective until 2023 tipe bendungan urugan tanah dengan inti tegak. Beberapa penyebab kegagalan yang umum ditemui pada earthfill dan rockfill dam adalah overtoping, tidak berfungsinya pintu air, stabilitas lereng, internal erotion dan piping. Internal erotion/piping adalah penyebab kegagalan bendungan terbesar yaitu $46,5 \%$ (fell et al, 2015). Penyebab kegagalan bendungan oleh overtopping dimana air yang melimpas melalui puncak bendungan menyebabkan terjadinya erosi serta longsoran pada tubuh

\section{Cite this as:}

Murdiani, K.M., Sangkawati, S. \& Sadono, K.W. (2020). Pemodelan Keruntuhan Bendungan Menggunakan HEC-RAS 2D Studi Kasus Bendungan Gondang, Kabupaten Karanganyar. Rekayasa, 13(2), 205-211. https://doi.org/10.21107/rekayasa.v13i2.6872 
bendungan khususnya pada bendungan tipe urugan. Internal erosion/piping adalah migrasi atau perpindahan material dari core atau material pondasi yang menyebabkan terbentuknya rongga didalam bendungan atau pada pondasi bendungan (Novak et al, 2007). Akibat migrasi butir halus ini menyebabkan adanya rongga didalam tanah dan rongga ini menyebabkan kecepatan aliran tanah menjadi besar sehingga kegagalan bendungan dapat terjadi. Bendungan type urugan mempunyai potensi keruntuhan akibat rembesan (seepage and piping). Sebanyak 50\% keruntuhan bendungan terjadi antara 0-5 tahun setelah dilakukan penggenangan (Azdan, M. D., \& Samekto, 2008).

Adanya potensi bahaya yang besar ini harus dibuat emergency action plan (EAP) dengan hatihati dan efektif. Input utama dari EAP adalah dam break analysis (DBA) (Lakshmi, V. A., Ambujam, N. K., \& Balamurugan, 2017). Sumber data untuk menyusun Action Plan ini adalah hasil dari Dam Break Analysis berupa simulasi keruntuhan bendungan dan dampak yang diakibatkan oleh keruntuhan bendungan berupa peta daerah terdampak. Menurut Peraturan Menteri Pekerjaan Umum dan Perumahan Rakyat Nomor 27/PRT/M/2015 tentang Bendungan, mengamanatkan bahwa pemilik/pengelola Bendungan diwajibkan untuk menyiapkan Rencana Tindak Darurat (RTD) terhadap Bendungan yang dikelolanya. Rencana Tindak Darurat bertujuan untuk menjadi pedoman atau petunjuk para pengelola Bendungan maupun pemerintah yang berada pada daerah yang terkena resiko apabila mana terjadi kondisi darurat pada Bendungan.

Lokasi Bendungan Gondang secara astronomis terletak diantara $110^{\circ} 40^{\prime}-110^{\circ} 70^{\prime}$ Bujur Timur dan $7^{\circ} 28^{\prime}-7^{\circ} 46^{\prime}$ Lintang Selatan tepatnya di ruas Sungai Garuda di Dusun Gondang, Desa Ganten, Kecamatan Kerjo, Kabupaten Karanganyar. Pembangunan Bendungan Gondang bertujuan untuk menyuplai daerah irigrasi seluas $4.680 \mathrm{Ha}$ di Kab. Karanganyar dan Kab. Sragen, air baku $200 \mathrm{lt} / \mathrm{dt}$ untuk Kab. Karanganyar, konservasi DAS (Ground Water Recharge), reduksi banjir 639,22 m3/detik .

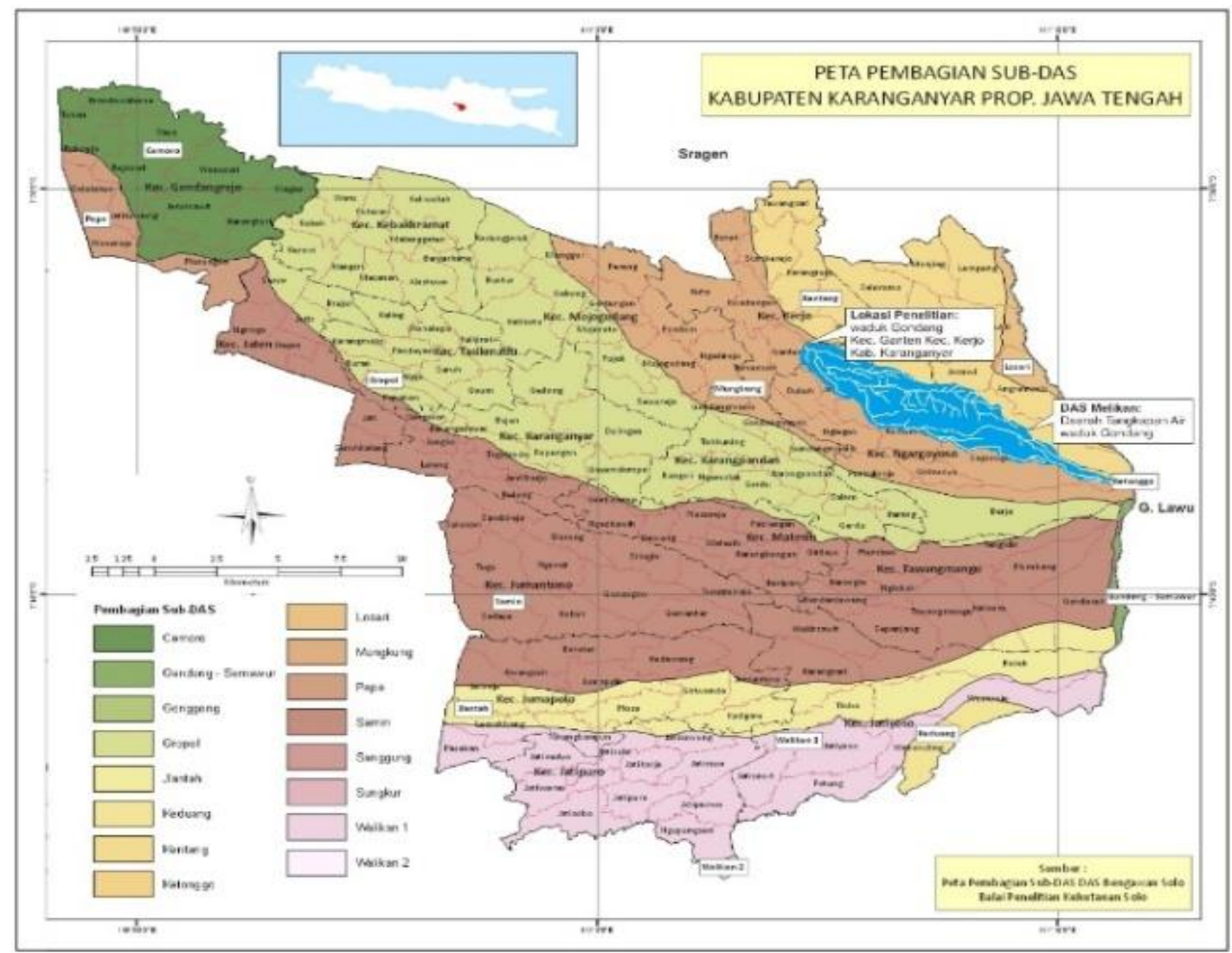

Gambar 1. Peta pembagian DAS Bendungan Gondang Kabupaten Karanganyar 


\section{METODE PENELITIAN}

Dalam makalah ini dilakukan analisis hidrologi untuk mendapatkan hidrograf keruntuhan bendungan (dam break) menggunakan program HEC-HMS 4.2.1 kemudian dilanjutkan dengan simulasi keruntuhan bendungan Dam Break Analysis (DBA) dengan menggunakan program HEC- RAS 5.0.6. Untuk pemetaan genangan menggunakan bantuan software ArcGIS 10.5 Output dari penelitian ini adalah Peta Genangan Banjir khususnya daerah Kabupaten Karanganyar akibat Keruntuhan Bendungan dan analisis hasil Simulasi Keruntuhan Bendungan mengenai kedalaman, waktu tiba banjir, lama genangan banjir, kecepatan aliran, jarak dari bendungan pada setiap lokasi terpilih di hilir bendungan. Penelitian ini dilaksanakan pada tahun 2019 di universitas Diponegoro Semarang dengan sumber data sekunder dari pihak Balai Besar Wilayah Sungai Bengawan Solo.

Input utama Dam Break Analysis 2D adalah peta digital, data hidrologi dan data teknis bendungan itu sendiri. Peta digital yang dibutuhkan setidak nya meliputi Digital Elevation Model (DEM), daerah tangkapan air (DTA) dan batas administrasi. Data Curah hujan terbaru yang digunakan adalah data 10 tahun terakhir hingga tahun 2005-2015 untuk mendapatkan hydrograph banjir. Data teknis bendungan berupa lengkung kapasitas waduk, sistem pengaliran dan pengukuran melintang dan memanjang sungai bagian hilir bendungan gondang sampai dengan muara. Jika terdapat bagian sungai yang belum diukur, dapat menggunkan input data peta DEM (Digital Elevation Model).

Keruntuhan bendungan (dam break) adalah terjadinya atau kemungkinan terjadinya keruntuhan bendungan atau tumpuan bendungan yang mengakibatkan keluaran air waduk dalam jumlah besar atau terjadi peningkatan jumlah keluaran air dari waduk yang tak terkendali, sehingga mengakibatkan keruntuhan bendungan.

HEC-RAS digunakan dengan menggunakan hasil perhitungan hidrograf aliran keluar dari bendungan dan routing banjir yang terjadi secara hidrolis di sepanjang lembah hilir. Proses keruntuhan bendungan dimulai dengan terjadinya rekahan (breaching). Rekahan adalah lubang yang terbentuk pada saat bendungan mengalami keruntuhan. Rekahan yang terjadi ditentukan dengan 2 cara yaitu overtopping dan piping. Breaching pada pemodelan ini menggunakan skenario piping dengan alasan bahwa piping menimbulkan dampak yang lebih luas (Xiong, 2011).

Skenario piping breach pada HEC-RAS, memulai perhitungan waktunya saat terjadi keluarnya de bit air dan material dalam jumlah yang signifikan. Waktu keruntuhan (breach time) dinyatakan sele-sai bukan berdasar tampungan waduk yang sudah kosong, tetapi tubuh bendungan yang sudah tidak mengalami perubahan akibat piping, erosi dan longsoran yang terjadi.

Skenario piping yang menjadi penyebab keruntuhan bendungan disimulasikan dengan menentukan elevasi titik pusat lubang rembesan (sumbu piping). Rekahan atau Breaching dimodelkan sebagai rekahan lubang rembesan dengan bentuk persegi panjang yang terlihat pada gambar 3 .

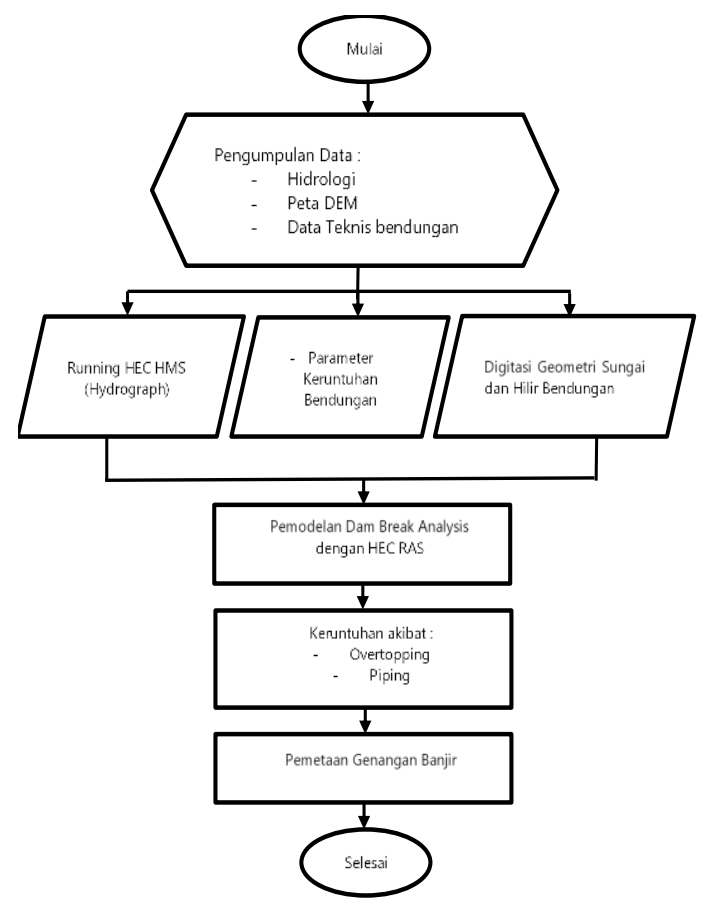

Gambar 2. Bagan Alir Penelitian 


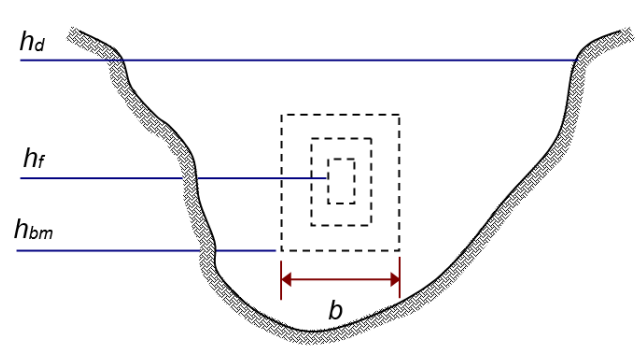

Gambar 3. Tampak Depan Rekahan akibat piping (Purwanto, P. I., Juwono, P. T., \& Asmaranto, 2017)

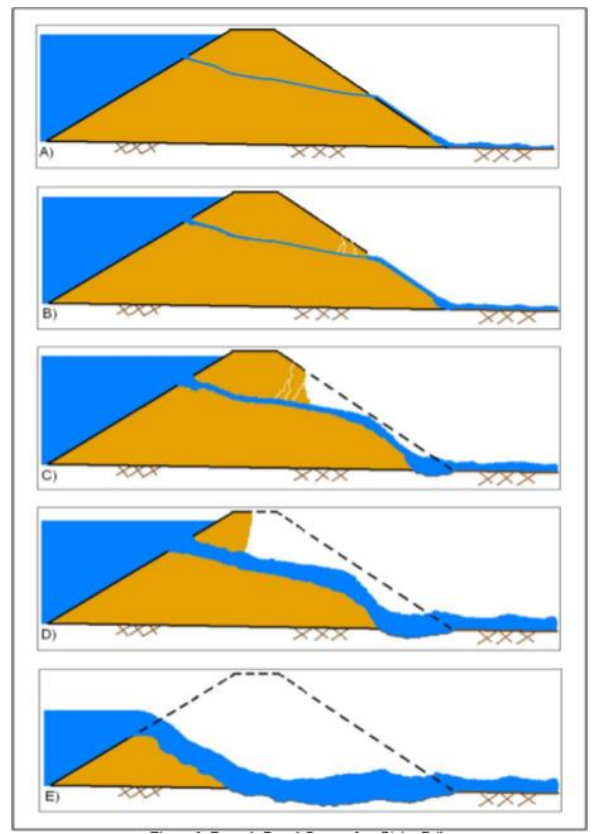

Gambar 4. Mekanisme Keruntuhan Akibat Piping (Hydrologic Engineering Center, 2014)

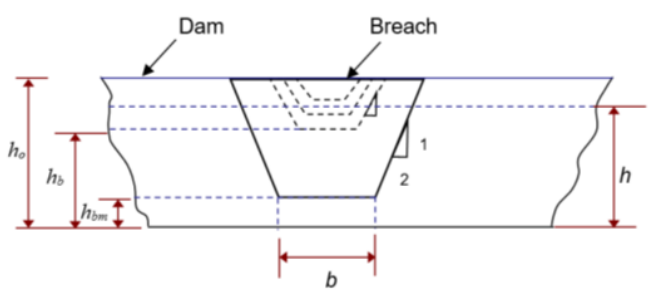

Gambar 5. Tampak Depan Perubahan Ukuran Rekahan akkibat Overtopping (Hydrologic Engineering Center, 2014)

Dapat dilihat pada Gambar 5, terjadinya rekahan dimulai dari satu titik lalu semakin membesar dengan kecepatan linier ataupun nonlinier dalam waktu puncak banjir sama dengan waktu terbentuknya rekahan $\tau$ hingga tercapai lebar (b) dan dasar rekahan tererosi setinggi elevasi $\left(h_{b m}\right)$ adalah elevasi dasar waduk.

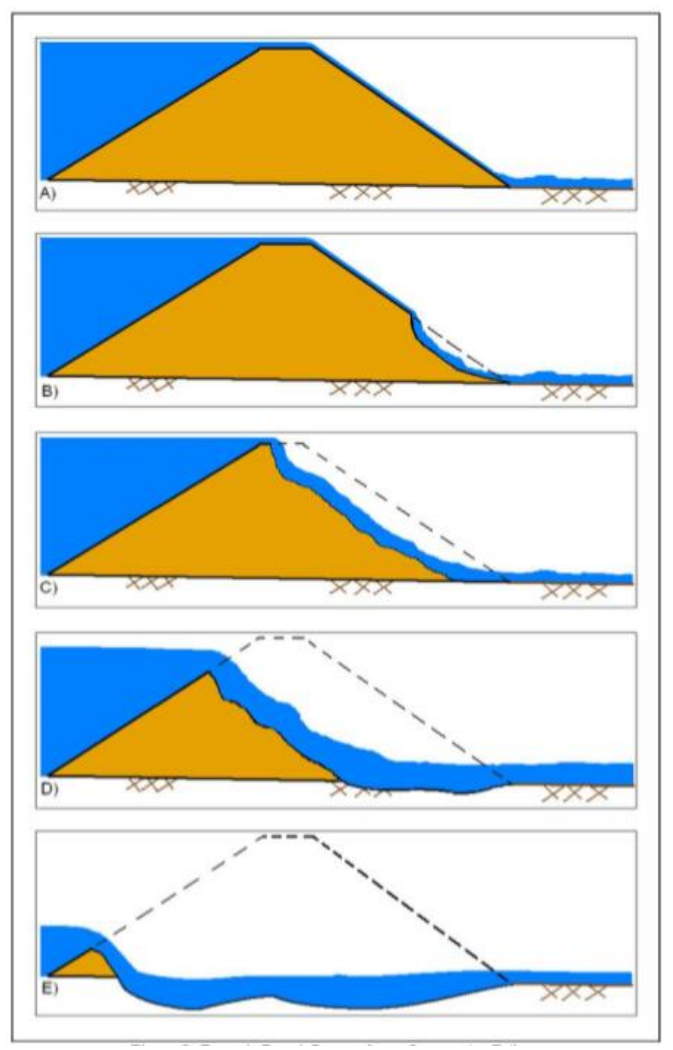

\section{Gambar 6 Mekanisme Keruntuhan Akibat Overtopping}

Dalam simulasi keruntuhan bendungan, didapatkan formasi rekahan yang sebenarnya dimulai apabila elevasi muka air (h) melebihi nilai (hf). Dalam pemodelan ini memungkinkan adanya simulasi melimpah (overtopping) dari suatu bendungan dimana rekahannya tidak akan terjadi hingga kapasitas aliran airnya cukup besar kemudian melewati puncak bendungan. Mekanisme overtopping dalat dilihat pada gambar 6.

\section{HASIL DAN PEMBAHASAN}

Luas Daerah Aliran Sungai (DAS) yang berpengaruh terhadap Bendungan Gondang adalah $20,19 \mathrm{~km}^{2}$. Sungai Utama yang melaliri air pada Bendungan Gondang yaitu sungai Melikan dengan panjang sungai $14,33 \mathrm{~km}$. Sumber air Bendungan Gondang yang mengalir dari bagian Hulu Gunung Lawu melewati Sungai Melikan dan sungai Garuda. Di Bagian muara aliran sungai bertemu dengan Sungai Bengawan Solo. 


\section{Analisis Banjir Rancangan}

Data hujan yang digunakan dalam analisis diambil dari 3 stasiun hujan yaitu stasiun Kerjo, stasiun Kemuning dan Stasiun Jenawi. Hujan rancangan terdiri dari 2 yaitu hujan rancangan tiap kala ulang tertentu yang analisisnya dengan distribusi frekuensi dan hujan rancangan maksimum boleh jadi (PMP) yang analisisnya

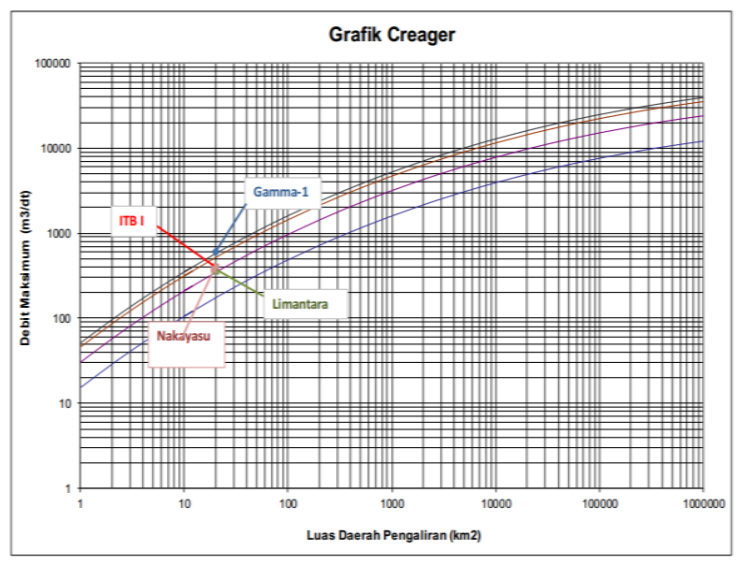

Gambar 8. Grafik Creager Waduk Gondang (Bengawan Solo, 2012)

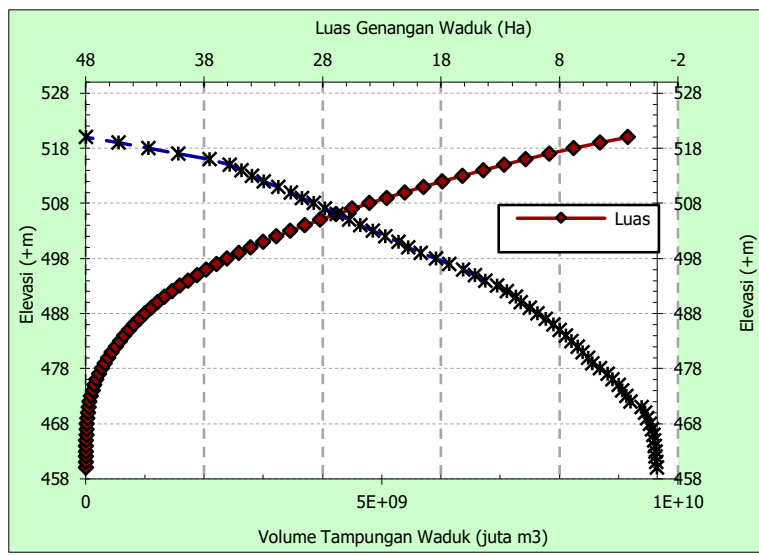

Gambar 9. Lengkung Kapasitas Waduk Gondang (Bengawan Solo, 2012)

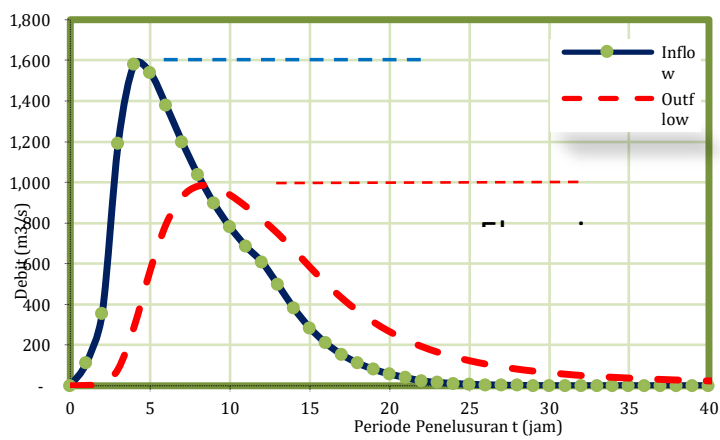

Gambar 10. Kapasitas Pelimpah Bendungan Gondang (Bengawan Solo, 2012) dengan cara Hersfield ataupun cara Isohyete, kemudian menentukan distribusi frekuensi mana yang mempunyai simpangan terkecil, maka dilakukan uji distribusi frekuensi dengan metode Smirnov-Kolmogorov dan Chi-Square. (Badan Standarisasi Nasional, 2012). Hidrograf Satuan Sintetik Gamma-1, ITB-1, Limantara dan Nakayasu dapat karena masih berada di dalam range kurva Creager. Kemudian data yang dipilih adalah hasil analisa terbesar dari keempat metode yaitu HSS Gamma-1 dengan nilai debit banjir sebesar 609,46 m3/detik. Kurva Creager dapat dilihat pada gambar 8 .

Lengkung kapasitas waduk ditunjukkan pada gambar 9, gambar genangan hasil pemodelan HEC RAS akibat piping atas dapat dilihat pada gambar 11 dan gambar genangan hasil

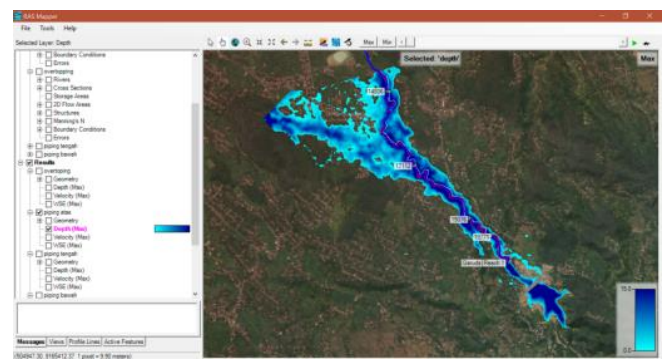

Gambar 11. Peta Genangan Banjir akibat piping atas (Hasil analisis, 2019)

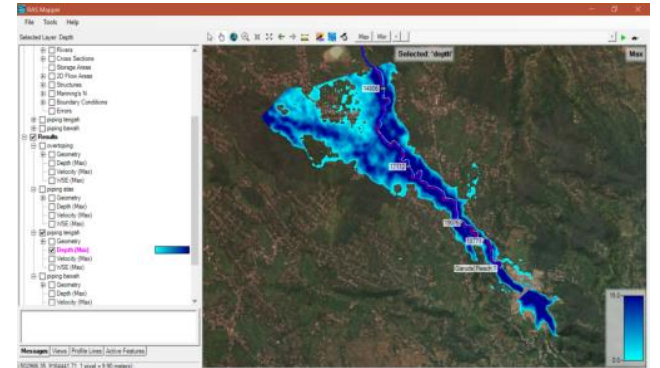

Gambar 12. Peta Genangan Banjir akibat piping tengah (Hasil analisis, 2019)

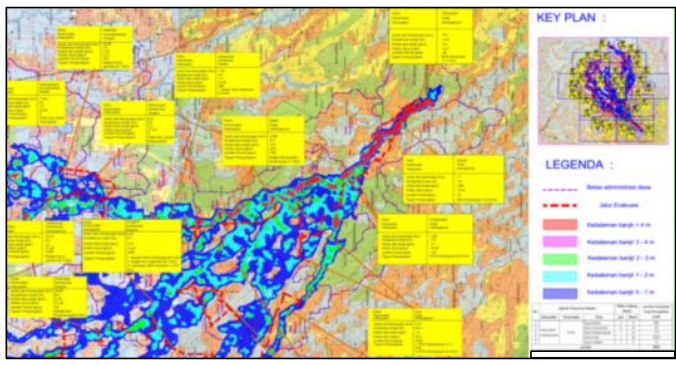

Gambar 13. Peta Daerah terdampak di kabupaten Karanganyar (Balai Besar Wilayah Sungai, 2018) 
pemodelan HEC RAS akibat piping tengah dapat dilihat pada gambar 12 .

Analisis Keruntuhan Bendungan Gondang dilakukan dengan dua skenario keruntuhan bendungan (rekahan), yaitu rekahan rembesan akibat piping atas (pada elevasi puncak pelimpah) dan rekahan limpasan akibat overtopping. Hasil dari skenario rekahan rembesan maupun rekahan limpasan berupa peta daerah tergenang akibat keruntuhan bendungan didapatkan dengan cara overlay (ditumpuk dalam 2 lapis) antara peta banjir hasil simulasi dengan peta administrasi daerah letak Bendungan tersebut. Berdasarkan hasil analisa keruntuhan bendungan akibat piping atas, maka didapatkan lokasi terpilih dapat dilihat pada tabel 1. Lokasi Terpilih daerah terdampak akibat skenario piping pada daerah Kabupaten Karanganyar, Provinsi Jawa Tengah adalah sebagai berikut :

Dambreak Bendungan Gondang pada skenario Overtopping debit PMF menghasilkan waktu datang banjir tercepat yang sampai ke pemukiman adalah 24 menit yaitu sampai di Desa Gempolan yang berjarak 0,6 km dari lokasi bendungan Gondang. Untuk skenario piping atas waktu datang banjir tercepat yang sampai ke pemukiman adalah 40 menit. Sedangkan skenario piping bawah waktu datang banjir tercepat adalah 32 menit dengan jarak terjauh genangan banjir adalah 19,5 km dari lokasi bendungan. Simulasi keruntuhan Bendungan Gondang akibat Piping Tengah pada elevasi +495 m. Dengan kenyataan tersebut diatas, maka keruntuhan Bendungan Gondang yang akan menimbulkan dampak paling besar jika terjadi Piping Tengah akibat banjir PMF dengan puncak debit $Q$ outflow $=902,40 \mathrm{~m}^{3} /$ det. Kejadian ini merupakan kondisi yang paling mungkin terjadi.

\section{KESIMPULAN DAN SARAN}

Pemodelan 2D pada analisis keruntuhan bendungan dapat memberikan data yang lebih rinci mengenai lokasi terdampak. Untuk daerah Kabupaten Karanganyar kedalaman banjir 4 meter dengan waktu datang banjir tercepat sampai ke pemukiman 24 menit. Pada pemodelan HEC RAS dapat ditingkatkan akurasinya dengan memperbaiki kualitas input peta DEM (Digital Elevation Model) serta data pengukuran sungai cross dan long section bagian hilir Bendungan. Hasil analisis keruntuhan bendungan dengan HEC-RAS 5.0.6 untuk pengolahan simulasi model keruntuhan bendungan, dan software ArcGIS 10.5 untuk pemetaan genangan dapat digambarkan peta banjir akibat keruntuhan bendungan adalah terdapatnya 6 daerah terpilih di Kabupaten Karanganyar yang terdampak banjir yaitu Desa Gempolan, Desa Batok, Desa Kwandungan, Desa Kuto dan Desa Ganten.

Tabel 1. Daerah penerima resiko akibat runtuhnya Bendungan Gondang ( BBWS BS, 2018)

\begin{tabular}{|c|c|c|c|c|c|c|c|}
\hline \multirow[t]{2}{*}{ No } & \multicolumn{3}{|c|}{ Daerah Penerima Resiko } & \multicolumn{2}{|c|}{$\begin{array}{c}\text { Waktu Datang } \\
\text { Banjir }\end{array}$} & \multirow{2}{*}{$\begin{array}{c}\text { Jumlah } \\
\text { Penduduk Yang } \\
\text { Diungsikan (Jiwa) }\end{array}$} & \multirow[t]{2}{*}{$\begin{array}{c}\text { Kedalaman } \\
\text { Banjir (m) }\end{array}$} \\
\hline & Kabupaten & Kecamatan & Desa & Jam & Menit & & \\
\hline 1 & Karang & Kerjo & Botok & 2 & 0 & 596 & $0-1$ \\
\hline 2 & anyar & & Gempolan & 0 & 24 & 38 & $>4$ \\
\hline 3 & & & Kwandungan & 1 & 12 & 115 & $2-3$ \\
\hline 4 & & & Kuto & 1 & 30 & 2045 & $0-4$ \\
\hline \multirow[t]{2}{*}{5} & & & Ganten & 1 & 6 & 15 & $1-2$ \\
\hline & & \multicolumn{2}{|c|}{ Jumlah } & & & 2809 & \\
\hline
\end{tabular}

Tabel 2. Letak Lokasi daerah penerima resiko kabupaten karanganyar (BBWS BS, 2018)

\begin{tabular}{|c|c|c|c|c|c|c|c|c|c|c|c|c|c|}
\hline \multirow{2}{*}{ No. } & \multicolumn{3}{|c|}{ Daerah Penerima Resiko } & \multirow{2}{*}{$\begin{array}{l}\text { Jarak Dari } \\
\text { Bendungan }\end{array}$} & \multicolumn{2}{|c|}{ Waktu Datang } & \multicolumn{4}{|c|}{ Tempat atau Lokasi Pengungsian } & \multirow{2}{*}{$\begin{array}{c}\text { Jumlah } \\
\text { Penduduk Yang }\end{array}$} & \multicolumn{2}{|c|}{ Waku Surut Banjir } \\
\hline & Kabupaten & Kecamatan & Desa & & Jam & Menit & Lokasi & Desa & Kecamatan & Jarak (km) & & Jam & Menit \\
\hline 1 & \multirow{7}{*}{$\begin{array}{c}\text { Kabupaten } \\
\text { Karanganyar }\end{array}$} & \multirow{7}{*}{ Kerjo } & Desa Botok & 9.1 & 2 & 0 & Majid Darrus Salam Kedawung & Botok & Kerjo & 1.7 & 596 & 20 & 24 \\
\hline 2 & & & Desa Gempolan & 0.6 & 0 & 24 & SDN Gempolan 1 & Gempolan & Kerjo & 0.8 & 38 & 13 & 6 \\
\hline 3 & & & \multirow{2}{*}{ Desa Kwandungan } & \multirow{2}{*}{2.4} & \multirow{2}{*}{1} & \multirow{2}{*}{12} & MTA Karanganyar & Kwadungan & Kerjo & 0.5 & \multirow{2}{*}{115} & \multirow{2}{*}{15} & \multirow{2}{*}{36} \\
\hline 3 & & & & & & & SDN Gempolan 1 & Gempolan & Kerjo & 1.0 & & & \\
\hline \multirow{2}{*}{4} & & & Desa Kuth & 33 & 1 & 30 & SDN Mojodoyong 4 & Kuto & Kerjo & 1.2 & \multirow{2}{*}{2045} & \multirow{2}{*}{19} & \multirow{2}{*}{36} \\
\hline & & & & & & & MTA Karanganyar & Kwadungan & Kerjo & 2.3 & & & \\
\hline 5 & & & Desa Ganten & 1.1 & 1 & 6 & SDN Kwandungan 2 & Ganten & Kerjo & 0.8 & 15 & 13 & 25 \\
\hline
\end{tabular}




\section{DAFTAR PUSTAKA}

Azdan, M. D., \& Samekto, C. R. (2008). Kritisnya Kondisi Bendungan di Indonesia.

Badan Standarisasi Nasional. (2012). SNI 7746.(2012) "Tata cara perhitungan hujan maksimum boleh jadi dengan metode Hersfield.

Balai Besar Wilayah Sungai, B. S. (2018). Penyusunan RTD Bendungan Gondang. Solo.

Bengawan Solo, B. B. W. S. (2012). Detail Desain Pembangunan Waduk Gondang Kabupaten Karanganyar.

Fell et al., R. (2015). Geotechnical Engineering of Dams.

Hydrologic Engineering Center, C. U. A. C. of E. (2014). Using HEC-RAS for Dam Break Studies.
Lakshmi, V. A., Ambujam, N. K., \& Balamurugan, R. (2017). Emergency Action Plan (EAP) For Sathanur Dam. International Journal OfLatEst Research in Science and Technology, 6(1), 46-51.

Novak et al., A. I. B. M. and C. N. (2007). Hydraulic Structures Fourth Edition.

Purwanto, P. I., Juwono, P. T., \& Asmaranto, R. (2017). Analisa Keruntuhan Bendungan Tugu Kabupaten Trenggalek, Jurnal Teknik Pen-gairan, 8(2), 222-230.

Xiong, Y. (2011). A Dam Break Analysis Using HEC-RAS. Journal of Water Resource and Protection, 03(06), 370-379. 